\title{
RECONSTRUCTING THE TRAJECTORY OF THE AUGUST I680 HURRICANE FROM CONTEMPORARY RECORDS
}

\author{
by D. Wheeler, R. García-Herrera, J. M. Vaquero, M. Chenoweth, and C. J. Mock
}

\author{
With historic data, including some of the earliest barometer observations in the region \\ and mariners' logbooks, it is possible to track the intensity and path of a storm \\ more than three centuries ago.
}

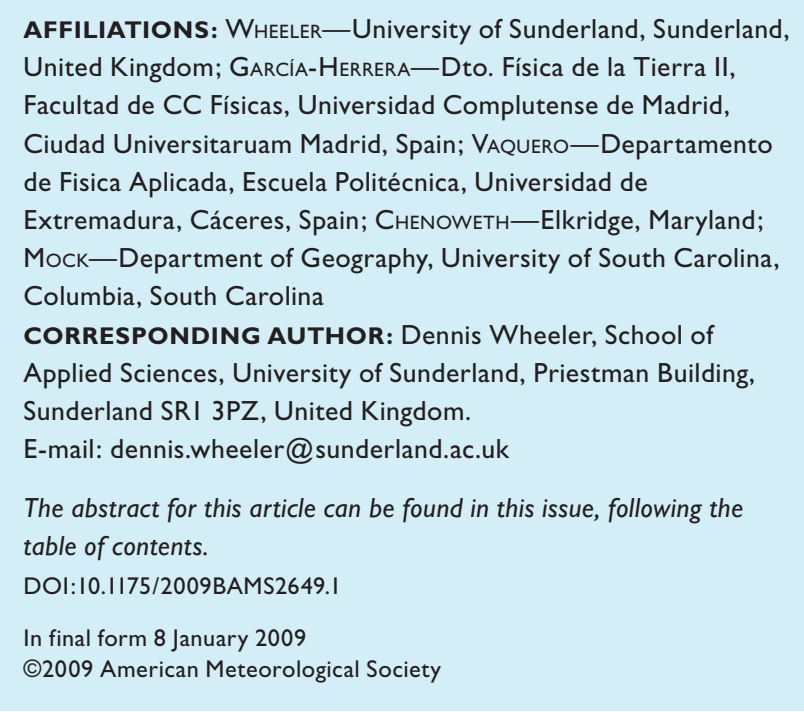

ropical hurricanes constitute a major element of the climatology of the North Atlantic and surrounding coastal areas. They have their origins in the tropical latitudes but are occasionally capable of sustaining their vigor as they recurve around the Atlantic subtropical anticyclone to eventually arrive on the coast of northwest Europe. The most important means by which such longevity is achieved is by undergoing extratropical transition (ET); that is, they do not dissipate when they move toward higher latitudes and over colder oceanic waters and regions with higher wind shear (Hart and Evans 2001, hereafter HE01). It has been estimated that around $46 \%$ of Atlantic tropical cyclones extend their life cycle by such means. Storms of this type have a significant impact on midlatitude weather and climate because they are usually associated with intense rainfall, strong winds, and large waves. The Atlantic coast of the United States, Europe, and the Mediterranean are often affected by severe weather episodes associated with ET cyclones (Jones et al. 2003; Krichak et al. 2004). The most comprehensive climatology of ET is that by HE01, which is based on the joint use of the National Hurricane Center (NHC) best-track database (Neumann et al. 1993; Jarvinen et al. 1984), the European Centre for MediumRange Weather Forecasts reanalysis (ERA) (Uppala et al.2005), and the National Climate Data Center daily rainfall dataset. The historical database of hurricanes is continuously updated through the North Atlantic hurricane databox (HURDAT; Landsea et al. 2004), but an important contribution to improving the record can be made through the reanalysis of premodern historical data and the recovery of overlooked data. Several efforts have shown recently that a notable body of such information exists in the form of archived documentary records, which can improve preexisting 
hurricane chronologies and identify unique extreme events not clearly evident in the modern record alone (García-Herrera et al. 2007; Chenoweth 2006; Mock 2008). In particular, ships' logbooks are rich in the provision of reports and observations of events over the seas. These logbooks are important because of their antiquity and abundance. This is nowhere better exemplified than in U.K. archives where more than 120,000 logbooks of English vessels for the period 1670-1850 (Wheeler and García-Herrera 2008) are estimated to exist. A recent paper (Vaquero et al. 2008) shows how the combined use of logbooks, newspapers, and other documentary sources can improve reconstruction of storms in the Atlantic.

The aim of this paper is to show how information from different documentary sources can be combined to derive a plausible track for a notable hurricane that occurred on August 1680. This case may represent one of the earliest and detailed documented examples of its kind. The 1680 hurricane has been reported by Millás (1968) in his chronology but it has otherwise been overlooked, although a previous paper by the authors (Chenoweth et al. 2007) documented the existence of the tropical phase for this hurricane. Here we examine in more detail its trajectory and history.

THE SOURCES AND RECONSTRUCTION. The Caribbean. The use of ships' logbooks in climatic studies was limited to case studies and small-scale exercises until the publication of the recent European Union (EU)-funded Climatological Database for the World's Oceans (CLIWOC; 1750-1850) in which more than 5000 logbooks were used to compile a

\begin{tabular}{|c|c|c|}
\hline Julian date & Description and source & Location \\
\hline $\begin{array}{l}\text { Early Aug } \\
\text { (date unknown) }\end{array}$ & $\begin{array}{l}\text { Merchant vessel from Cadiz dismasted } \\
\text { Arrived Barbados 8th (LG) }\end{array}$ & $13^{\circ} 40^{\prime} \mathrm{N}$ mid-Atlantic \\
\hline 8 Aug & $\begin{array}{l}\text { Ditto: confirmed in the logbook of HMS } \\
\text { Richmond }\end{array}$ & \\
\hline II Aug & $\begin{array}{l}\text { Logbook of HMS Richmond confirms } \\
\text { hurricane activity, the storm setting in } \\
\text { overnight }\end{array}$ & $\begin{array}{l}\text { Originally } 12 \text { miles } \\
\text { east of Barbados but } \\
\text { running northeast for } \\
10 \text { hours }\end{array}$ \\
\hline 12 Aug & $\begin{array}{l}\text { Logbook of HMS Richmond indicates an } \\
\text { abating of the hurricane }\end{array}$ & $\begin{array}{l}\text { Southerly course takes } \\
\text { HMS Richmond back to } \\
\text { Barbados }\end{array}$ \\
\hline 12 and 13 Aug & $\begin{array}{l}\text { Sharpe's barometric data identifies the } \\
\text { passage of the hurricane }\end{array}$ & Barbados \\
\hline 13 Aug & $\begin{array}{l}\text { Calendar of State papers describes the } \\
\text { hurricane }\end{array}$ & St. Kitts \\
\hline 13 Aug & Calendar of State papers; ditto & Martinique \\
\hline 15 Aug & $\begin{array}{l}\text { Spanish broadsheet describes the } \\
\text { destruction on Santo Domingo }\end{array}$ & $\begin{array}{l}\text { Santo Domingo island } \\
\text { and city }\end{array}$ \\
\hline 22 Aug & $\begin{array}{l}\text { The logbook of HMS Hunter describes } \\
\text { a mid-Atlantic hurricane on night of the } \\
22 \text { nd into the } 23 r d\end{array}$ & $\begin{array}{l}\text { Lat. } 48^{\circ} 19^{\prime} \mathrm{N} \text { Lon. } \\
20^{\circ} \mathrm{W}\end{array}$ \\
\hline 23 Aug & Shipwreck at St. Mount's Bay (LG) & Cornwall \\
\hline 23 Aug & Storm and shipwreck (LG) & Swansea \\
\hline 23/24 Aug & Storm and shipwreck (LG) & Plymouth \\
\hline 23/24 Aug & $\begin{array}{l}\text { Severe storm reported in the logbook of } \\
\text { the vessel Patience }\end{array}$ & St. Helens, Portsmouth \\
\hline 23/24 Aug & Stormy weather (LG) & Portsmouth \\
\hline
\end{tabular}

near-global database of daily observations. This paper draws on the methods and procedures developed in that project (see www.ucm.es/info/cliwoc and GarcíaHerrera et al. 2005) but requires that particular attention be given to the antiquity of the logbooks, which are among the oldest existing examples of their kind and predate the CLIWOC study period by nearly a century. This reconstruction, however, draws on a far wider range of sources. These include not only logbooks of ships of the English Royal Navy but also an early printed newssheet publication from Spain and a similar series of items from England. Table 1 summarizes the various sources that form the evidence base of the following discussion.

The reconstruction begins on 1 [11] August $^{1}$ when the official English Crown publication the London Gazette for 18 [28] October noted:

\footnotetext{
${ }^{1}$ At this time England was still using the Julian calendar, which at that time was 10 days out of agreement with the more accurate Gregorian calendar. The latter date is given in brackets whenever English sources are cited. Spain had already adopted the Gregorian calendar; England did not do so until 1752.
} 
The $8^{\text {th }}$ instant [18 August] arrived here a Spanish ship that sailed from Cadiz with the New Spain fleet. The supercargo says that on the first of this month in the latitude 13 degrees 40 minutes they lost all their masts except their mizan in a hurricane and were thrice in a manner overset and that to save themselves they were forced to heave 13 great guns overboard and then with help of jury masts and spare sails to their great comfort made this island where they intend to refit and then to proceed on their voyage.

This account is substantiated by an entry in the logbook of the English vessel HMS Richmond for 8 [18] August, in which it was noted "... this day arrived a Spanish ship from Cadiz who had lost her main mast and foremast by ye violence of the last storm . . ye weather faire, the wind trade as before at $E N E^{t}$ to $E^{t}$ to ESE. ${ }^{\text {". }}$ The location of the storm at this time has been estimated in Chenoweth et al. (2007) to be east of Barbados (see also Fig. 1).

Conditions before the arrival of the stricken Cádiz trader are described in various accounts, and those found in the Richmond's logbook are informative. On 1 [11] August when 12 miles ( $18 \mathrm{kms}$ ) east of Barbados, her captain (unknown) noted ". . a att 8 att night ye winds came at $N E^{t}$ and blow fresh ... between 10 and 11 the winds blew more fresh so we furled our foresails." When in open ocean, it was more commonplace to use the nautical day, which began 12 hours ahead of the civil (Harries 1928). On this occasion, however, the logbook provides accounts by the civil day, a possible consequence of being relatively close to shore.

The entry for 2 [12] August testifies to the hurricane's growing vigor: ye clewgarnetts ${ }^{3}$ we scudded before it for the space of 10 hours those courses NEbE ye winds at $S$ for 4 hours $N E^{t}$ ye winds att SEbS NEbN the winds at SSE."

In the most severe of conditions, sailing ships would "scud" before the wind on bare poles (i.e., be driven in the same direction as the wind, often with no sails), the important objective of this resort being to avoid being caught broadside on to the wind. This evidence of at least storm force and probably hurricane (although the term is not used) strength winds provides a date of 11 August 1680 shortly after midnight for its arrival at the easternmost point of Barbados. The progression of winds around the compass-northerly, westerly, and then southerlysuggests the passage of the system to the north of the island. By the next day, however, it had moved on and the Richmond's entry reads:

This morning between 2 \& 3 o clock ye storm abated so wee sett our main courses \& att 4 . . ye winds at ESE att one o clock in the afternoon we had sight of 12 or 14 sayle some to windward some to leeward at 2 in ye afternoon we spoke w $[i]$ th a pinke $e^{4} w[$ hi]ch for safety putt to sea out of Carlisle Road... ye weather faire $w[i]$ th fresh gailes of wind att ESE \& SEbE.

Given the latitude of Barbados and the evidence from the London Gazette report, the trajectory of the cyclone was thus far westerly along $13^{\circ} \mathrm{N}$. The Richmond's logbook suggests that the strongest winds, before which she ran for 10 hours, were southerly, from which it can be inferred that the hurricane center had passed Barbados and was moving generally westwards.

\footnotetext{
"This morning att 3 of the clock the wind came more N[orth]erly and between 4 \& 5 we stood about upon a starboard tack she comeing to the WbN and falling off to the WSW yn [then] ye winds veared to the w[es] tward . . att 4 att night it blowd and raind verry hard we furld our mainsail with

${ }^{2}$ Original spelling in cited old documents is retained.

${ }^{3}$ Clewgarnet: part of the system by which the sails were managed.

${ }^{4}$ Pink: a small merchant vessel.
}

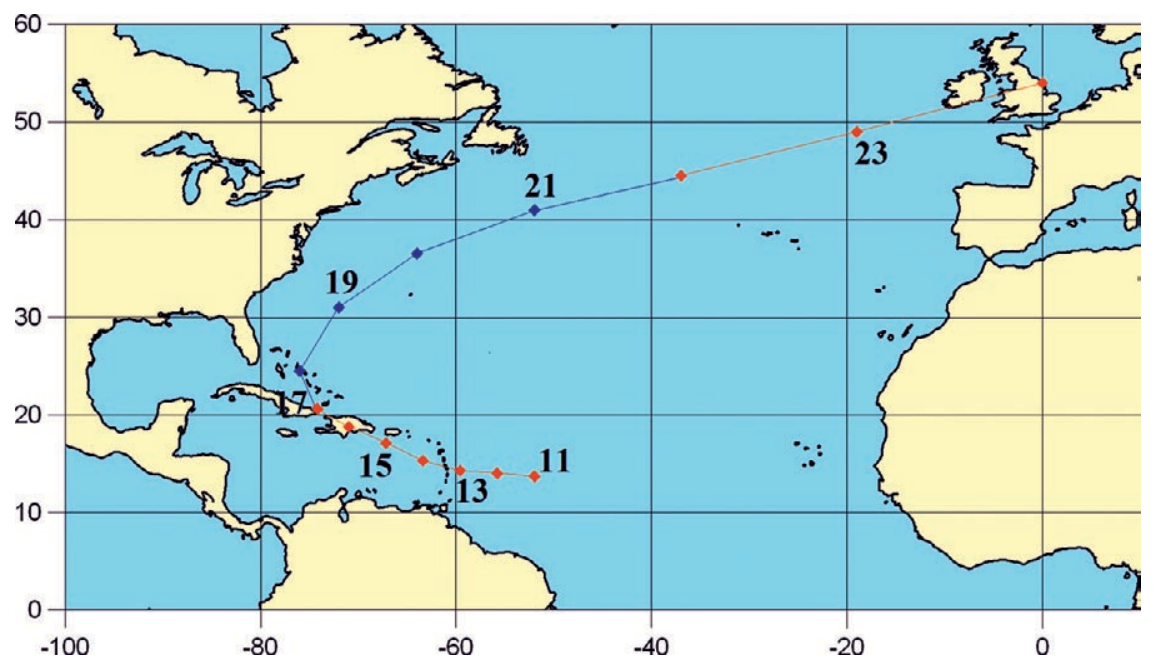

FIG. I. Reconstructed trajectory of the hurricane of Aug 1680. The blue section of the trajectory indicates those periods for which data and information are lacking and the reconstruction is more speculative. 
Of greater immediate and historical importance is the evidence provided by the Barbados plantation owner William Sharpe (Chenoweth et al. 2007), who had received a barometer from the Royal Society of London three years earlier. The timing suggested by his record agrees broadly with that outlined above. In both cases the wind is recorded as increasing and backing to the west at about 3 p.m., becoming generally southerly and intense thereafter, although neither source uses the term "hurricane." Table 2 summarizes Sharpe's account of the event in which there exists no record of severe damage for Barbados, again suggesting that the storm was probably strengthening at that time. The lowest recorded air pressure on the island is estimated after correction to be 29.71 inches during the afternoon of 3 [13] August. This pressure is not notably low and indicates that the storm did not pass directly over the island but at some distance that cannot with confidence be determined. Further evidence for this suggestion is found in Sharpe's notes (Table 2) in which his reference to "terrible thunder" suggests the sort of charged convective activity that is more commonly associated with the outer regions of hurricanes (Molinari et al. 1999). All local sources, however, acknowledge a decrease in storminess as early as 4 [14] August.

Further evidence is provided by the state papers of correspondence from the West Indian colonies held in the U.K. National Archives. An unsigned letter dated 6 [16] September written on St. Christopher (modern St. Kitts) describes events of the previous days thus:

Yesterday arrived a ffrench shallop belonging to a ship lately come out of ffrance that is yet above at
Martinico w[hi]ch reports there hath been a more violent storm among the ffrench islands which hap[pe] ned on the 3/13 August last than was ever known before; hath blown down all their houfes, churches and fforts; upon the island of Martinico hardly left a tree or plant growing; also the Citadel which Count Blenac had been soe long a building is all ruin[e]d

The description of substantial buildings such as churches being destroyed leaves little doubt as to the nature of the storm being one of hurricane strength. The story of relentless destruction continues with a Spanish broadsheet (Anonymous 1680) that carries the translated heading "A true account given of the dreadful hurricane that overcame the island and port of Santo Domingo on 15 August 1680." The style of this communication is florid in the extreme with allusions to Greek mythological characters, but the sense of reality it conveys is no less convincing for that. The day is reported to have dawned clear and bright, but by 9 a.m. the sky had assumed a dark and threatening appearance. A red-hued halo is described around the sun, while animals and birds fell ominously quiet. By midday the storm had arrived with "furious" northerly winds that "created havoc" and "Instead of breezes the Divine Powers created in this transparent air an atmosphere so violent and blowing a hurricane [the first occasion on which the event was recorded as such] such as had never been recorded in history." In the fields trees were uprooted (although we are given no indication of their size), while in the city of Santo Domingo buildings, including what must be regarded as a well-constructed governor's residence, were reduced to rubble. In the harbor a fleet of French vessels were destroyed and the list of nearly 20 eminent officers and gentlemen who perished can only be thought of as representing a small proportion of the number of mariners who shared their fate. No great significance can be attached to statements such as "had never been recorded in its history," which tend to be widely used when describing extreme weather events.

More reliable are the descriptions, both from Martinique and Santo 
Domingo, of widespread structural damage to buildings of differing degrees of constructional quality that suggest perhaps a major hurricane, although it is difficult at this distant point in time to use this evidence to place the event on the Saffir-Simpson scale (Saffir 1973; Simpson 1974) with any confidence. This same broadsheet served Millás (1968) to include the event as hurricane 49 in his chronology. Regarding the trajectory, he notes, "I believe that this storm, coming from the Atlantic, crossed over the southern region of the Windward Islands with weak or moderate intensity; moving slowly in a northerly direction, it developed over the eastern Caribbean Sea into a severe hurricane. Its center afterwards crossed over, or slightly west, of the city of Santo Domingo, still moving in a northwesterly or northerly direction." However, and importantly in the context of calling upon such newly developed sources as are here cited, both the current evidence and that of Chenoweth et al. (2007) provide a new and revised interpretation of this part of the storm's route that did not move northward but in a west-northwest direction and with greater strength than Millás suggested. The subsequent trajectory after landfall in Hispaniola is open to conjecture.

There is no evidence of it having made landfall on the American mainland. Neither has a search of the logbook collection in English archives provided any information on its passage over the nearby seas, but the American mainland was at this time sparsely populated and this absence of evidence does not necessarily suggest that such an event did not take place.

The North Atlantic and British Isles. The Royal Navy ship HMS Hunter had set off from Bermuda to England on 19 [29] July 1680. Having enjoyed an uneventful passage, on 12 [22] August she had an encounter with a storm when at $48^{\circ} \mathrm{N}$ and $42^{\circ} \mathrm{E}$ of Bermuda, ${ }^{5}$ placing her at $\sim 22^{\circ} \mathrm{W}$ (of the Greenwich meridian). The logbook entry for this (nautical) day reads as follows:

wind at SW and SSW till 6 o clock last night when it veered to the NW very fresh, we handed our topsails and set out courses three foot lower than ordinary and stood ENE 4 leagues [?] and run 8 knots; at 8 last night the wind increased so much at $N W$ and NNW that it proved a violent storm in a moment, which separated us from my Lord and the Pink. [The governor of Jamaica was on a ship that lost its mainmast by stress of weather, according to the London Gazette of 9 September; this may be the "Lord" that is being written about.] We used all possible means and lowered our mainsail and foreyards [indecipher- able] but it continued furious and we could not show our courses, they were blown out of the bolt ropes immediately with the spritsail, topsail and the main topsail studding sail, we had an ugly sea our gunwales was frequently underwater for near an hours time and the sea came up to the coverings of the hatches with the weather, sea at the same time beating in upon us till we was thought she would hardly ever right again, without cutting our masts by the boards having so much water between decks we would have weared her though it was dangerous but could not possibly do it though her mizzen was hauled up and the yard struck upon the quarter deck. I ordered the carpenter to cut three holes on the gun deck to let the water down in hold and pumps to be set to work and our men to bail what they could which brought her to be very jocund again in less than an hour... the extremity of the storm continued until this morning.

This account in terms of both the timing and description of the events suggests the possibility that the storm is the same as the hurricane that struck the West Indies earlier that month and had now recurved around the Azores anticyclone, moving northeasterly and reaching the mid-Atlantic on 22 August. The evidence, however, is by no means conclusive, and it is a matter of regret that no logbook evidence can be found for the western Atlantic to support the conjecture. Nevertheless, the derived eastward translation rates of about $50 \mathrm{~km} \mathrm{~h}^{-1}$ fall within the range of what might be expected of such an event. Moreover, recent evidence suggests that it is unlikely that the storm encountered by HMS Hunter was not the same system that had ravaged Santo Domingo some 8 days earlier. The HURDAT dataset provides evidence that over the 50-yr period of 1958-2007 there have been only three cases when in August or September tropical systems approaching the British Isles were not associated with systems crossing the general Santo Domingo area some 8 days earlier; these were in 1963 (unnamed storm 3), 1967 (Hurricane Chloe), and 1998 (Hurricane Karl).

According to HE01, the ET during the peak season around September is likely to occur at higher latitudes (about $45^{\circ} \mathrm{N}$ or higher). The logbook provides evidence for wind speeds consistent with those of a hurricane and at this latitude, probably undergoing

\footnotetext{
${ }^{5}$ In these distant times there was no universal zero meridian, and ships estimated their easting or westing with regard to some arbitrarily selected landmark, usually the last port of call. In this case, the evidence suggests the port to have been Bermuda.
} 
or completing transition to a tropical cyclone somewhere northward of $45^{\circ} \mathrm{N}$. Importantly, and suggesting the possibility of ET having taken place, the storm appears to have remained a vigorous deep cyclone after its encounter with HMS Hunter and during its passage over England.

Events over the British Isles unfold on 13 [23] August when the London Gazette makes reference to storms along the southwest coast of England and Wales. The first of these, dated for 13 [23] August writes of a "very violent" storm at Swanzey (Swansea) with shipwrecks along the South Wales coast. A report from Falmouth for 16 [26] August relates the wrecking of a Dutch merchant ship with ". . very stormy weather for three days past." For 17 [27] August it was noted from Portsmouth that ". . we had such stormy weather that the like has not for several years past been known."

More informative evidence is found in the logbook of the merchant ship Patience prepared by one of her officers, Isaac Hunt. This vessel was moored in Portsmouth awaiting favorable winds to head down the English Channel to North Africa. On 13 [23] August the following was recorded (the logbook being kept by the civil day):

about Noon thick hazy and sum Rain but in the Afternoon about 5 a clock in the Afternoon the Wind board about to the SSW and the SA very hard storm of Wind with a very dark wind and sky and Sum Rain with a Great Sea continued all night Much Rain and Wind with squalls and frets of wind in the Rain so we lowered our yards [indecipherable] and struck our topmast before night but in the night the wind board about to SSW \& SSWbS A very hard storm.

The situation on the following day was scarcely improved:

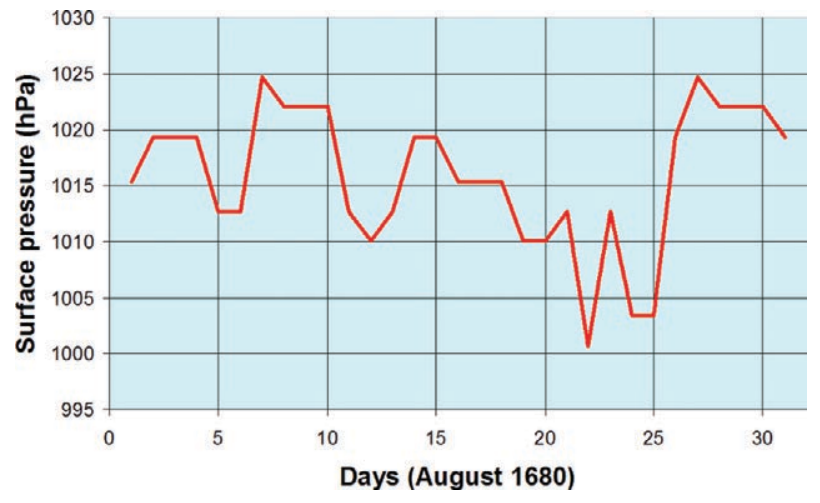

FIG. 2. Daily corrected air pressure data for Aug 1680 based on the Morin series (Paris).
This day very bad weather \& very thick and much rain \& $A$ very hard storm of wind with many hard gusts in rain Between the WSW and WbSW So about 4 in the Afternoon we let fall our Sheet Anchor underfoot... and so much for this day.

The sheet anchor was needed to prevent the vessel from being driven ashore by the strength of the winds. The storm persisted for yet another day, and it was not until August 15 [25] that any sense of it abating can be detected:

This day and all the night Before very thick dirty Rainy Weather \& A Hard Storm of Wind continuing at $S W b W$ \& $S W$ \& $W S W$ but about 12 at noon the wind board about to the WbN, WNW and the NWbW not altogether so much wind as before and at night the wind board about to the $N$ \& WbSW \& so continued all the night After a fresh gale of wind and rain.

The evidence suggests that the storm made rapid progress from the mid-Atlantic to Europe, whereupon it seems to have slowed in its trajectory with violent winds persisting for up to 3 days through the English Channel. The descriptions from Isaac Hunt's logbook support the evidence from the London Gazette of a protracted period of storm activity from a single almost stationary system over the British Isles with a long period of decline into quiescence on 16 [26] August when he records "... indifferent good weather." The winds being principally from the west indicates that the storm center has passed over more northern areas, possibly midland England, but the backing from west to north on the 25th suggests the passage of a cold front, the latter again supporting the conjecture that this storm had undergone ET. Using all such evidence, the proposed trajectory has been reconstructed (Fig. 1).

Finally, the air pressure data gathered by Louis Morin in Paris can be called upon to provide instrumental evidence to support the logbook narrative accounts. Morin was a Paris-based scientist whose daily observations have already been of service (Slonosky et al. 2001). Figure 2 shows Morin's corrected daily sea level pressure data for August 1680. The month's lowest pressure was $1000.7 \mathrm{mb}$ on the $22 \mathrm{nd}$, but this is too early to be associated with this storm; in fact, it not only suggests a preceding and distinct system but also helps to account for the protracted period of storm activity in the region between 22 and 25 August. The evidence of low pressure on the 24th and 25th $(1003.3 \mathrm{mb})$ is more probably, by virtue of the timing, associated with the 
transformed tropical system now in an extratropical state. Cyclonic proximity of this nature, even when associated with transformed tropical systems, is not unknown; a recent example has been explored in detail by Browning et al. (1998) when ex-hurricane Lili had transformed and reintensified along much the same trajectory as that proposed for this event.

Comparison of such a pressure with the contemporary mean for August (based on the Morin series) of $1017.3 \mathrm{mb}$ suggests markedly cyclonic conditions.

Taking all daily August readings for the 1670-1713 period, this value is 2.4 standard deviations below the mean and therefore falls outside the 95\% range of natural variability. Allowing for the distance of some 250 miles between Portsmouth and Paris, the central pressure may have been yet more anomalous and the storm can be regarded as unusual, at least in the statistical sense of its pressure.

\section{DISCUSSION AND CONCLUSIONS. The} trajectory shown in Fig. 1 matches well with those derived from instrumental data for other more recent ET cyclones (see Fig. 1 in HE01). According to the climatology of HE01, the cyclone is likely to have accelerated its progress in the final part of the trajectory. This is usually the case because, according to Jones et al. (2003), a decaying tropical cyclone often evolves into a fast-moving and occasionally rapidly developing extratropical cyclone. That it may also bring to Europe storm activity in summer that is more typical of winter conditions is another important factor. As examples of the latter, Jones et al. cite Hurricane Floyd in 1993 and Hurricane Lili in 1996. The trajectories of these hurricanes, together with others from August to September over the past century with similar trajectories and progression, are presented in Fig. 3, one of the key criterion here being any storm passing within 100 miles of $40^{\circ} \mathrm{N}$ and $45^{\circ} \mathrm{W}$. It might, however, be noted that only Charley (1986) offers a mid-Atlantic trajectory close to that of the 1680 event; the others agree far less well. It can be suggested therefore that the 1680 storm might be unusual in respect of its trajectory, at least by more recent standards. This lack of frequent and recent analogues and of records of other events from the late seventeenth century makes it difficult to provide any estimate of the reliability or error term in the reconstruction.

It is known that ET cyclones tend to extend over wider areas and to increase their translation speeds. The latter may have been the case in this example, at least until its very final stages over the British Isles. Extratropical transition occurs in baroclinic zones and tends to be preferentially located in the western Atlantic, where warm and cold air-sea contrasts are often large. It is possible that the system that was encountered by HMS Hunter had therefore already transformed. The general evolution of transformed Hurricane Lili (1996) studied additionally by Browning et al. (1998) again offers evidence of behavior similar to that of the 1680 event.

Based on a set of diverse documentary sources (most of them unexplored to date), we propose this event as the earliest detailed and near-complete documented track of an Atlantic hurricane. It also demonstrates how narrative accounts can be interpreted to provide useful estimates of climatic behavior and how evidence from different sources can be integrated into a comprehensive overview.

ACKNOWLEDGMENTS. The Louis Morin data were kindly supplied and corrected by Dr. V. C. Slonosky. The U.K. element of the research for this paper was funded by the EU Project 017008-2 (Millennium). The Spanish Ministry of Science and Education provided partial support through Grant MEC. CGL2005-25107-E/CLI. 


\section{REFERENCES}

Anonymous, 1680: Relación verdadera en que se da cuenta del horrible huracán que sobrevino a la Isla y Puerto de Santo Domingo de los Españoles el dia quinze de Agosto de 1680. Printed by Lucar Antonio de Bedmar, Madrid, 4 pp.

Browning, K. A., G. Vaughan, and P. Panagi, 1998: Analysis of an ex-tropical cyclone after its reintensification as a warm-core extratropical cyclone. Quart. J. Roy. Meteor. Soc., 124, 2329-2356.

Chenoweth, M., 2007: A reassessment of historical Atlantic basin tropical cyclone activity, 1700-1855. Climatic Change, 76, 169-240, doi:10.1007/s10584005-9005-2.

— , J. M. Vaquero, R. García-Herrera, and D. Wheeler, 2007: A pioneer in tropical meteorology: William Sharpe's Barbados weather journal. April-August 1680. Bull. Amer. Meteor. Soc., 88, 1957-1964.

García-Herrera, R., G. P. Können, D. Wheeler, M. R. Prieto, P. D. Jones, and F. B. Koek, 2005: CLIWOC: A climatological database for the world's oceans 1750-1854. Climatic Change, 73, 1-12.

— , L. Gimeno, P. Ribera, E. Hernández, E. González, and G. Fernández, 2007: Identification of Caribbean basin hurricanes from Spanish documentary sources. Climatic Change, 83, 55-85, doi:10.1007/s10584-0069124-4.

Harries, H., 1928: Nautical time. Mariner's Mirror, 14, $364-370$.

Hart, R. E., and J. I. Evans, 2001: A climatology of the extratropical transition of Atlantic tropical cyclones. J. Climate, 14, 546-564.

Jarvinen, B. R. C., C. J. Neumann, and M. A. S. Davis, 1984: A tropical cyclone data tape for the North Atlantic basin, 1886-1983: Contents, limitations and uses. NOAA Tech. Memo NWS NHC 22, NOAA/ National Hurricane Center, 22 pp.

Jones, S. C., and Coauthors, 2003: The extratropical transition of tropical cyclones: Forecast challenges, current understanding, and future directions. Wea. Forecasting, 18, 1052-1092.

Krichak, S. O., P. Alpert, and M. Dayan, 2004: The role of atmospheric processes associated with Hurricane Olga in the December 2001 floods in Israel. J. Hydrometeor., 5, 1259-1270.

Landsea, C. W., and Coauthors, 2004: The Atlantic hurricane database re-analysis project. Documentation for 1851-1910. Alternations and additions to the HURDAT database. Hurricanes and Typhoons: Past, Present and Future. R. Murman and K.-B. Liu, Eds., Columbia University Press, 177-221.
Millás, J. C., 1968: Hurricanes of the Caribbean and Adjacent Regions, 1492-1800. American Academy of the Arts and Sciences of the Americas, $328 \mathrm{pp}$.

Mock, C. J., 2008: Tropical cyclone variations in Louisiana, U.S.A., since the late eighteenth century. Geochem. Geophys. Geosyst., 9, Q05V02, doi:10.1029/2007GC001846.

Molinari, J., P. Moore, and V. Idone, 1999: Convective structure of hurricanes as revealed by lightning locations. Mon. Wea. Rev., 127, 520-534.

Neumann, C. J., B. R. Jarvinen, C. J. McAdie, and J. D. Elms, 1993: Tropical cyclones on the North Atlantic Ocean 1871-1992. NOAA Historical Climate Series, Vol. 6-2, 193 pp.

Saffir, H. S., 1973: Hurricane wind and storm surge. Mil. Eng., 423, 4-5.

Simpson, R. H., 1974: The hurricane disaster potential scale. Weatherwise, 27, 169-186.

Slonosky, V. C., P. D. Jones, and T. D. Davies, 2001: Instrumental pressure observations and atmospheric circulation from the 17th and 18th centuries: London and Paris. Int. J. Climatol., 21, 285-298.

Uppala, S. M., and Coauthors, 2005: The ERA-40 re-analysis. Quart. Roy. J. Meteor. Soc., 131, 29613012.

Vaquero, J. M., R. García-Herrera, D. Wheeler, M. Chenoweth, and C. J. Mock, 2008: An historical analogue of 2005 hurricane Vince. Bull. Amer. Meteor. Soc., 89, 191-201.

Wheeler, D., and R. García-Herrera, 2008: Ships' logbooks in climatological research: Reflections and prospects. Ann. New York Acad. Sci., 1146, 1-15, doi:10.1196/annals.1446.006.

\section{SOURCES}

S everal archive sources have been used in the prepara$\int_{\text {tion }}$ of this paper, including the following:

Logbook of HMS Richmond. The U.K. National Archives. ADM/5I/3949 [5]

Logbook of HMS Hunter. The U.K. National Archives. ADM/5I/3870 [I]

Logbook of the Patience. The British Library. Sloane Collection 2034.

Correspondence in state papers. The U.K. National Archives. COI/46/5

The London Gazette for 1680. British Library, Burney Papers, Vol. 84A (microfilm)aciliquis dolobo 